\title{
Environmental education as a tool of sustainable development of territories
}

\author{
Marina Vidrevich*, Galina Pakhalchak, and Irina Pervukhina \\ Ural State University of Economics, 8 Marta Str., 62, 620144 Ekaterinburg, Russia
}

\begin{abstract}
The paper deals with the environmental element of the concept of sustainable development. The purpose of the paper is to explore the issue of municipal solid waste management in the Russian Federation and in Sverdlovskaya Oblast. More specifically, it examines the context for successful implementation of the National Ecology Project and the garbage reform against a background of public pressure. There is a need for an integrated approach to broaden the public 'green' outlook by engaging educational institutions, business organizations, and mass media. To maintain an ecological balance is in itself a way to ensure sustainable development of territories. The authors believe that environmental education may significantly contribute to raising awareness among consumers and producers for the purpose of sustainable development, and serve as a possible measure of preventing public discontent.
\end{abstract}

\section{Introduction}

The concept of sustainable development is defined [1] as development that meets the needs of the present without compromising the ability of future generations to meet their own needs. This overall purpose calls for a set of specific efforts towards building an inclusive, sustainable and resilient future for people and planet. For sustainable development to be achieved, it is essential to harmonize three core elements: economic growth, social inclusion and environmental protection. These elements are interconnected and all are crucial for the well-being of individuals and societies.

According to [2], as of 201715 percent, or $2500000 \mathrm{~km}^{2}$, of the territory of the Russian Federation were environmentally dangerous to human life and health. This area is home to 40 percent of the Russian population. Sustainable development in Russia is constricted by environmental degradation. Economic damage from environmental pollution accounts for 4-6 percent of the country's GDP. With estimates of possible negative consequences for human health this figure can amount to 15 percent.

The role of the environmental element in attaining sustainable development of the country and its territories is hard to overestimate. In the Soviet period, the legal framework for industrial and municipal waste management was underdeveloped and existed as a set of instructions and recommendations without a regular and careful monitoring of how these instructions were followed [3]. Since 1991, Russia has pursued inefficient policy with

\footnotetext{
*Corresponding author: mbv@usue.ru
} 
regard to waste generation, accumulation and disposal, which has been causing negative impact on a country's overall environmental and resource efficiency framework and has resulted in suboptimal use of raw materials and energy.

The volume of both industrial and municipal wastes in Russia has been steadily increasing in recent years [4]. According to the data available from the Accounts Chamber of Russia (www.ach.gov.ru), in 2014, the size of waste disposal sites covered over $4 \mathrm{mln}$ hectares. This annually increases by 400 thousand hectares.

In recent years, the issue of waste management, specifically the growing landfill troubles, has become a concern to both the public and the government. In 2018, the Russian government launched the National Ecology Project [5] to improve environmental protection in Russia towards 2024. The project focuses on different areas, among which are the quality of air and water, sewage in rivers, forest preservation and waste management. Part of this plan is to introduce a solid waste management system for industrial and household waste and to liquidate all unauthorized landfills in cities by 2024 .

As of 2019, there were 243 waste processing plants, 50 waste sorting complexes and 10 incinerators in Russia [6]. Up to 30 percent of waste disposal facilities in regions throughout the country do not meet sanitary requirements, and expansion opportunities are severely limited. The volume of municipal solid wastes (MSW) in Russia has been steadily increasing in recent years: according to available data, annually 56-65 mln metric tons of MSW are generated, i.e., more than 330 kilograms per capita. It is expected that by 2025 MSW generation in Russia will reach 450 to 500 kilograms per capita per year. Around 95 percent of all MSW was sent for disposal, a situation which, inevitably, has negative environmental and economic consequences. According to official data, just from four to seven percent of rubbish is recycled in Russia [7, p. 14]. This falls far below France's 43 percent or Germany's 68 percent achieved in 2017, according to Eurostat. In the United States, for example, up to 40 percent of all municipal waste is recovered; EU Member States typically recover around 60 percent of municipal waste - ranging from 25-30 percent in the Czech Republic, Slovakia, and Poland to 95-99 percent in Austria, Belgium, and Switzerland [8].

In Russia, the most popularly used method of waste disposal today is the landfill. This process of waste disposal focuses attention on burying the waste underground. Currently, the country has a total of 1000 municipal solid waste landfills, 5500 authorized and 17000 unauthorized landfills [9]. This challenge is compounded by the fact that between 50 and 70 percent of Russia's waste collection and haulage infrastructure is obsolete. Moreover, formal MSW collection services do not extend to a number of small towns and villages.

In recent years, waste management has emerged as a subject of heated debate [7]. Unauthorized landfills, overflowing container sites in courtyards, and burning landfills fuel more public ire. Garbage dumps are among the most acute environmental problems for 16 percent of the population [10]. With the issue emerging as a major cause of public discontent, President Vladimir Putin in December 2019 announced that the recycling rate will increase to 60 percent by 2024 with the help of 200 new waste sorting centers.

The purpose of the paper is to explore the issue of MSW management in the Russian Federation and in Sverdlovskaya Oblast. More specifically, our core tasks are to examine the context for successful implementation of the National Ecology Project and the garbage reform against a background of public pressure. We would also like to consider how environmental education may contribute to raising awareness among consumers and producers for the purpose of sustainable development, and serve as a possible measure of preventing public counterstand. 


\section{Method}

The methodological framework is based on systematic approach, which employs general scientific methods: observation, comparative analysis, formal logic, description and interpretation, including deduction, induction, and generalisation.

\section{Results and discussion}

Starting on January 1st, 2019 Russia adopted the garbage reform. The measures being implemented within this reform are aimed at improving the environmental situation in the country and designed to reduce the number of unauthorized dumps taking place and to make the market for recycling transparent and civilized [11]. Every Russian region will switch to the new waste management system that changes the rules of the collection, sorting, recycling, and disposal of garbage. The removal of MSW which used to be part of housing maintenance services is now operated under community services. Each region must select its MSW management operators, i.e. legal entities responsible for garbage disposal from pickup to landfill. However, the Minister of Natural Resources and Environment of the Russian Federation Dmitry Kobylkin admits the existence of some factors that may adversely affect the course of the reform. Among others are unreasonable revisions of tariffs and standards for accumulation carried out by regional authorities; the postponement of the start of work by some regional operators; the lack of a differentiated approach to setting standards for urban and rural residents, and low collection of payments for MSW.

Sverdlovskaya Oblast is one of the most industrialized regions in the Russian Federation. It mirrors all-country environmental challenges and is characterized by excessive concentration of production facilities, mainly environmentally hazardous, obsolete technologies and equipment for waste recycling, separation and/or incineration. Sverdlovaskaya Oblast ranks last in the environmental rating of the Russian Federation entities [12] and is among the top 10 regions with municipal waste challenges, according to the ranking of Finexpertiza (https://finexpertiza.ru/).

One of the main environmental issues in Sverdlovskaya Oblast is the fact that most waste collection and haulage infrastructure is obsolete and does not comply with environmental legislation. The volume of accumulated waste in Oblast exceeds 9 bln tons. The Oblast landfill area covers over 17000 hectares. Of Oblast's 445 industrial and agricultural waste disposal sites, 45 are bona vacantia and contain about $150 \mathrm{mln}$ tons of wastes covering an area of 700 hectares. The state register of waste disposal facilities includes 192, located in Sverdlovskaya Oblast, of which 153 are for industrial and agricultural wastes, and 39 are for MSW. A significant number of waste disposal facilities in the region do not meet sanitary requirements,

Annually Sverdlovskaya Oblast generates about $1.6 \mathrm{mln}$ tons of MSW, 10 percent of which are disposed and neutralized. The existing MSW management system is based on the priority of burial or temporary storage of wastes at special landfills, which accounts for 88 percent of the total volume.

Currently Sverdlovskaya Oblast is running the Regional Waste Management Program, set to take place between 2019 and 2030. It also has joined the garbage reform launched in the Russian Federation in 2019. The first five months of the reform implementation in Sverdlovskaya Oblast showed some positive changes: more than 300 unauthorized landfills were closed; over 100 new garbage collection sites were organized, and more than 6500 new containers were installed. At the same time the garbage reform has caused discontent among the local population. A poll taken by the website Garbage Reform. Russia (https://мусорная-реформа.pф/) showed that only 7.2 percent of respondents acknowledged the need for the reform and supported the changes resulting from its 
implementation, while the majority believed that the reform aimed at profiteering regional operators by charging the garbage collection fee to households, which eventually led to a rise in utility bills. The question resonated and has triggered numerous protests in Russia. In February 2020, the Oblast saw an upwelling of public anger over the reform. Protesters complained about a low quality of services provided by local operators and a lack of enthusiasm at the government level; and demanded the resignation of the Minister of Housing and Public Utilities. Local residents called for justification of utility tariffs. They suspected that their local administration official plans for waste management were masquerading as sustainable while effectively hiding problems from view.

The lack of transparent information about ongoing projects allows protesters to validate their actions. For instance, one of the first projects of the Regional Program was the construction of a waste sorting complex and waste disposal landfill in Krasnoufimsk, planned for 2021-2023. By now, because of the local protests the construction has been almost 'frozen'. Initially, distorted and misleading information about the construction of the incinerating facilities took residents to the streets of the town. Later, the expert report with negative conclusions that the facilities did not comply with environmental requirements triggered a new wave of rallies.

An effective counter-measure of fuelling population discontent and distrust between authorities and residents could be public awareness of the importance of environmental education which falls within the greater discourse on education for sustainable development [13]. The purpose of environmental education is to develop environmental competence among members of the society, which is understood as a responsible and competent attitude to the environment and environmental protection, including liability for waste production and improper waste disposal. The main tasks of environmental education are to disseminate knowledge about environmental safety, eco-saving technologies, and environmental legislation [14].

In order to alter the negative attitude toward the garbage reform the following forms of environmental education can be recommended. Accurate and relevant information on environmental issues and advanced technologies should be placed on official websites, in social networks, regional and local media. The public should be more informed about the course of the garbage reform. This information could be disseminated in a form of a booklet written by a group of academics, practitioners, and representatives of the environmental community. Lectures and discussion platforms devoted to the garbage reform projects should be shared in social networks. There should be regular meetings between activists and environmentally competent representatives of local authorities, public organizations, research and engineering organizations. At the stage of selecting a construction site for MSW facilities and during the operation of the facilities, population should be aware how authorities, public organizations, local community and regional operators communicate via media and social networks.

In Sverdlovskaya Oblast, much attention is paid to building the environmental education system [15] which takes into account practices of successful environmental projects for schoolchildren and students. One of the most promising forms of informal environmental education, in our opinion, is EurasiaGreen, an international contest of research projects targeting high school and university students and young scientists. This contest is held annually at the Ural State University of Economics (Ekaterinburg). The purpose of the contest is to enhance sustainable innovation and creativity in the field of protection and rational use of natural resources; and to introduce effective green technologies. Additional benefits from participating in EurasiaGreen are the development of managerial and research skills, which ensures better employability and career prospects for young people. 
Since 2006, Sverdlovsk Regional Branch of the All-Russian Society of Nature Conservation has been coordinating the Youth Ecological Construction Brigade Program, which aims to protect the environment, to promote environmental awareness, to draw public attention to environmental issues, and to improve environmental performance of young people. To achieve the stated goals the project addresses the following objectives: to involve high school and university students in environmental projects; to offer special training to the program participants (e.g., training programs for foremen and park instructors); to conduct research and conservation work. The program is evolving successfully: the geography of the project is expanding; the range of tasks has increased as a result of improved skills of the brigade members. The program is gaining popularity among young people and it will continue to develop.

The Green Wave is another program of Sverdlovsk Regional Branch of the All-Russian Society of Nature Conservation, launched in 2004. It is a large-scale project that focuses on engaging children in field-based summer activities. Fieldwork provides children with a chance to observe nature and the environment. More specifically children are involved in taking care of green areas in settlements, natural parks, spring-adjacent territories. Since the start of the project hundreds of tons of rubbish were removed, thousands of trees were planted, hundreds of directional signs were installed in areas of natural scenic beauty.

It is also worth mentioning the Springs project that has been implemented since 2000. Its purpose is to preserve natural resources and offer environmental education programs to the public. The program is successfully developing and gradually gaining social significance for the local community by uniting business and public; environmentally concerned activists and educational institutions; representatives of older and younger generations.

The largest environmental events held on the regular basis in Sverdlovskaya Oblast, among others, are: Clean Banks, the all-Russian campaign for cleaning water reservoirs; Live, Forest! the all-Russian campaign for planting trees; Crystal Compass National Award; Clean Games Environmental Quest (targeting trash collection and sorting); Fairy Taiga Educational Quest. These types of activities engage broad masses of local population and every year their number grows.

Large industrial enterprises of the Urals do not remain outside environmental events. For instance, Sredneuralsky copper-smelting plant supports the UNESCO Billion Trees initiative: since 2011, 55,000 trees have been planted in Revda, Pervouralsk and the Chusovaya river basin.

The goal of all these projects is to reinforce a responsible attitude to the environment, which is based on a new way of thinking. The latter involves adherence to moral and legal principles of nature management and promotion of sustainability in environmental education.

\section{Conclusion}

No doubts that raising awareness of environmental issues and ways of resolving them among adult population is an important tool for environmental education. However, since value systems, lifestyles, and attitudes are formed at an early age, education for children is of particular importance. There is a need for an integrated approach to broaden the public 'green' outlook by engaging educational institutions, business organizations, and mass media. To maintain an ecological balance is in itself a way to ensure sustainable development of territories. Environmental education for sustainable development is a process that lasts throughout life, from early childhood to higher education and adult education, and goes beyond formal education. A higher level of eco-literacy might result in better understanding of the economic and environmental feasibility of the garbage reform 
and create the most favorable climate for its successful implementation for the benefit of the sustainable development of the society.

\section{References}

1. United Nations Sustainable Development Goals. https://www.un.org/sustainabledevelopment/development-agenda/

2. S.N. Bobylev, L.M. Grigorieva, Environmental priorities for Russia. Analytical center at the Government of the Russian Federation (2017)

3. G.A. Arakelova, Rus. J. of Resources, Conservation and Recycling, 1(2019)

4. K. Kovalenko, N. Kovalenko, The problem of waste in the Russian Federation. MATEC Web of Conferences 193, (2018)

5. The National Ecology Project, (2018) http://static.government.ru/media/files/7jHqkjTiGwAqKSgZP2LosFTpKo66kEu2.pdf

6. Ye. Slobodin, How many waste processing plants are there in Russia? (2017)

7. The Civic Chamber of the Russian Federation. Analysis of the effectiveness of measures to ensure the processing of municipal solid waste and proposals to ensure that the views of citizens of the Russian Federation are taken into account when constructing facilities used for processing these wastes, (2019)

8. Municipal Solid Waste Management: Opportunities for Russia. World Bank Report, (IFC, 2012)

9. Recycling and waste management in Russia, Schneider GROUP, (2020)

10. President of Russia's Council on Civil Society and Human Rights. Prevention of waste generation as a necessary condition for ensuring the environmental rights of citizens and the successful implementation of the National Ecology Project (2019)

11. Waste Management Reform, SPIEF 21. https://forumspb.com/en/news/news/reformav-sfere-obraschenija-s-othodami/

12. Ecological rating of the entities of the Russian Federation. Green Patrol (2019)

13. M. Bonnett, The Curriculum J., 24(2) (2013)

14. Federal Law "On Environmental Protection" dated January, 10, 2002 No 7-FZ

15. A.A. Arinushkina, IOP Conf. Ser.: Earth Environ. Sci. 274, (2019) 